\title{
Change in diet of the Eurasian eagle owl (Bubo bubo) suggests decline in biodiversity in Wadi Al Makhrour, Bethlehem Governorate, Palestinian Territories
}

\author{
Zmeny v potrave výra skalného (Bubo bubo) naznačujú pokles biodiverzity vo Wadi Al \\ Makhrour, Betlehemský guvernorát, Palestínske územia
}

\author{
Zuhair S. AMR, Elias N. HANDAL, Faysal BIBI, Mohammad H. NAJAJRAH \& Mazin B. QUMSIYEH
}

\begin{abstract}
The diet of the Eurasian eagle owl (Bubo bubo) was studied in Wadi Al Makhrour, Bethlehem, Palestinian Territories in 2015 with fresh and several year old pellets. Three species of arthropods, one reptile species, at least four bird species, and six species of mammals were recovered from the studied pellets. Black rat (Rattus rattus) was the most common prey (37.0\%), followed by the southern white-breasted hedgehog (Erinaceus concolor) (29.4\%) and birds (21.8\%). Comparison of recent and older pellets showed change in diet composition. Recent pellets contained more Rattus rattus compared to older ones. Older pellets included more naturally-occurring species such as Meriones tristrami, Microtus guentheri, and Rousettus aegyptiacus, which were absent in newer pellets.
\end{abstract}

\begin{abstract}
Abstrakt: Potrava výra skalného (Bubo bubo) bola študovaná vo Wadi Al Makhrour, Betlehem, Palestínske územia, v roku 2015 z čerstvých a niekol'koročných vývržkov. Vo vývržkoch boli identifikované tri druhy článkonožcov, jeden druh plaza, najmenej štyri druhy vtákov a šest' druhov cicavcov. Potkan tmavý (Rattus rattus) bol najčastejšou korist'ou (37,0 \%), nasledovaný ježom východným (Erinaceus concolor) (29,4 \%) a vtákmi (21,8 \%). Porovnanie čerstvých a starších vývržkov poukazuje na zmenu v zložení potravy. Súčasné vývržky obsahovali väčší podiel potkana tmavého než staršie vývržky. Staršie vývržky obsahovali viac prirodzene sa vyskytujúcich druhov, ako sú Meriones tristrami, Microtus guentheri a Rousettus aegyptiacus, chýbajúcich v súčasných vývržkoch.
\end{abstract}

Key words: Eurasian eagle owl, Bubo bubo, diet change, Palestine

Zuhair S. Amr, Department of Biology, Jordan University of Science \& Technology, P.O.Box 3030, JO-22110 Irbid, Jordan. Email: amrz@just.edu.jo.

Elias N. Handal, Mohammad H. Najajrah, Mazin B. Qumsiyeh (corresponding author), Palestine Museum of Natural History, Mar Andreas campus, Bethlehem University, PS-90907 Bethlehem, Occupied Palestinian Territories.

E-mail: eliashanda193@gmail.com,mhnajajrah93@gmail.com, mazin@qumsiyeh.org.

Faysal Bibi, Museum für Naturkunde, Invalidenstraße 43, DE-10115 Berlin, Germany. E-mail: Faysal.Bibi@mfn-berlin.de.

Acknoweledgements: We would like to thank the Palestinian American Research Center for their help and logistic support during this study.

\section{Introduction}

The Eurasian eagle owl (Bubo bubo) is an inhabitant of rocky slopes and valleys (wadis) of humid and semiarid Mediterranean habitats in the Palestinian Territories (Shirihai 1996). The eagle owl diet has been studied in various countries in Western Asia, including Syria (Shehab 2004), Iran (Obuch 2014), Turkey (Obuch 1994; De Cupere et al. 2009) as well as European countries such as Greece (Papageorgiou et al. 1993; Alivizatos et al. 2005), Italy (Marchesi et al. 2002), Slovakia (Obuch \& Karaska 2010) and Spain (Donázar 1987). The diet of the closely-related Pharaoh eagle owl (Bubo ascalaphus), a desert-dwelling species is known from Western Egypt (Goodman 1990), northern Saudi Arabia (Evans \& Bates 1993), and Jordan (Amr et al. 1997; Rifai et al. 2000; Shehab \& Ciach 2008).

Diets of other owl species in historical Palestine include the barn owl (Tyto alba) (Dor 1947; Heth 1991; Pokines \& Peterhans 1997; Yom-Tov \& Wool 1997; Tores \& Yom-Tov 2003; Charter et al. 2007, 2009; Obuch \& Benda 2009), and the tawny owl (Strix aluco) (Obuch 2011).

No information on the diet of the Eurasian eagle owl in Palestine is available to date. The present study is the 
first to provide information on the diet of this species, and to investigate diet changes between recently regurgitated pellets and old prey remains from fragmented old pellets found close to their nests.

\section{Materials and methods}

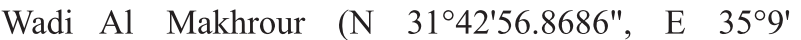
$\left.25.5522^{\prime \prime}\right)$ is located to the north-west of the city of Bethlehem and is part of a valley system of about 20 $\mathrm{km}^{2}$ that starts from Beit Jala around Al-Walaja and runs through the villages of Al Khader, Battir, Husan and Nahhalin, continuing to collect runoff to reach major discharge into the Mediterranean via Wadi Es-San. The hills face west and so precipitation is higher on this side of the Jerusalem hills than on the eastern side (700-800 $\mathrm{mm}$ per year vs less than $500 \mathrm{~mm}$ ) and the mountain generates several springs of water as well as smaller water discharge leaking through rocks and generating wet areas (from which the name Al Makhrour comes, meaning in Arabic "the leaky"). Al Makhrour valley itself is now $2.6 \mathrm{~km}^{2}$ of natural areas interspersed with agriculture, accounting for about $80 \%$ of the total area of the entire wadi system. Looking at satellite images going back 15 years, we note that built-up areas have taken $0.2 \mathrm{~km}^{2}$ or roughly $7 \%$ of the natural area. We estimate the rate of decrease in natural area was even higher before, because the Israeli authorities increased their pressure to stop building work by the na- tive Palestinians. Al Makhrour is an area with high biodiversity value with abundant evergreen oak (Quercus calliprinos), olive (Olea europaea) and spiny hawthorn (Crataegus aronia). Cliffs and small caverns are quite common and are frequented by the Eurasian eagle owl (Fig. 1). Other common birds known in the area include palm dove (Streptopelia senegalensis), jackdaw (Coloeus monedula), rock dove (Columba livia), jay (Garrulus glandarius), chukar partridge (Alectoris chukar) and the little owl (Athene noctua).

Thirty-seven intact pellets in addition to many broken older remains (judged as at least several years older by their color and position in the pile under the roosting site) were collected from a roost hole of $B$. bubo in Al Makhrour. Each pellet was numbered and its location in the pile identified (newer pellets on top). Pellets were placed in Petri dishes, soaked in water for 15 minutes, and then all bones and other arthropod remains were removed and cleaned. The number of individual animals in each pellet was determined by matching lower jaws of reptiles and mammals, bills of birds and arthropod remains (e.g. chelicerae, telsons) to the maximum possible degree.

Statistical analysis was performed using the SPSS package including Pearson's chi-squared test $\left(\chi^{2}\right)$ analysis of categorical data obtained by analysis of prey items identified in pellets and in prey remains (see results).

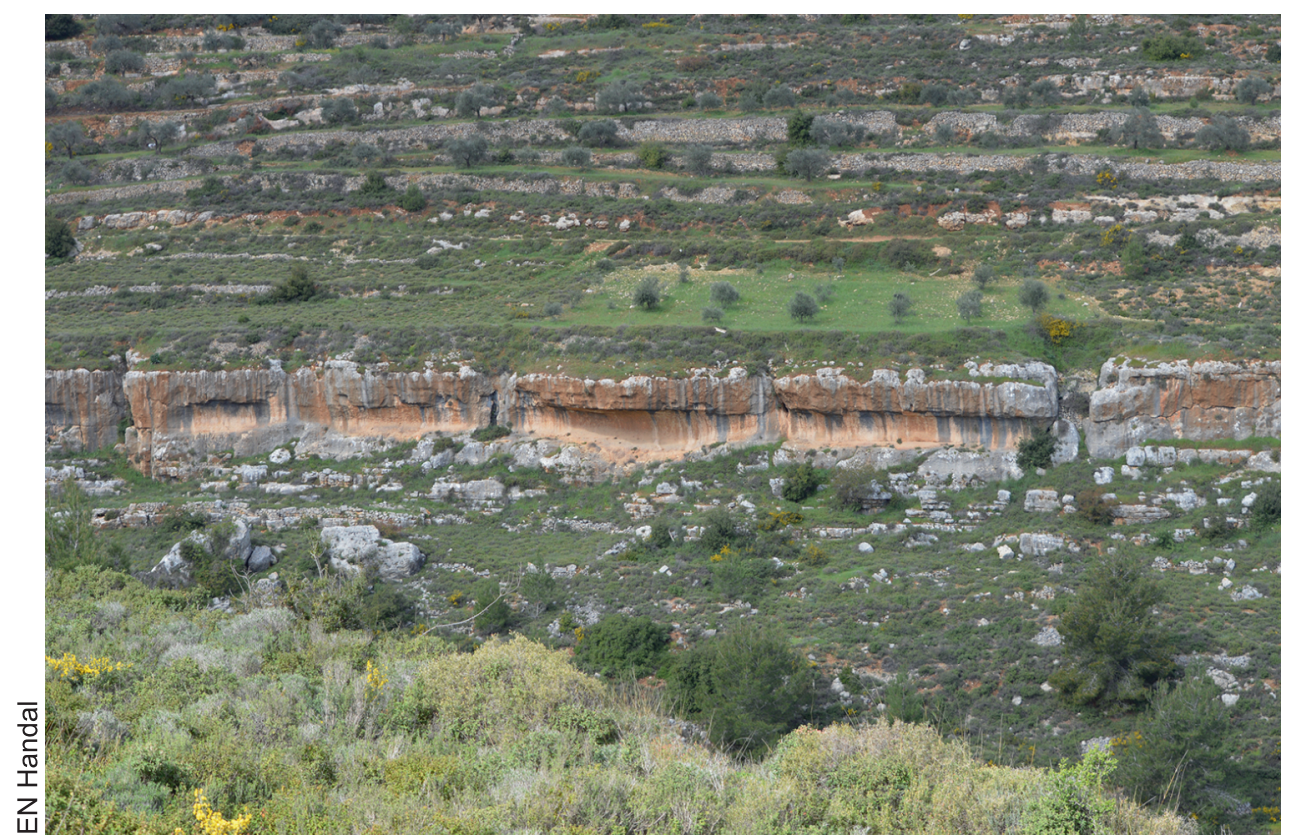

Fig. 1. Cliffs where the Eurasian eagle owl nests in Wadi Al Makhrour.

Obr. 1. Skalné steny vo Wadi Al Makhrour, kde hniezdi výr skalný. 


\section{Results}

P r e y c o m p o s i t i o $n$

A total of 92 individuals representing three species of arthropods, one reptile species, at least four bird species and six species of mammals were identified during the study (Tab. 1). Black rat (Rattus rattus) was the most common prey $(37 \%)$, followed by the southern whitebreasted hedgehog (Erinaceus concolor) (29.4\%) and birds $(21.8 \%)$. In terms of biomass, mammals made up the highest percentage in comparison to other prey.

Each pellet contained the remains of at least one mammal or bird. The number of identified items per pellet ranged from 1 to 4 prey items (average 1.51). $59.46 \%, 35.14 \%$ and $5.04 \%$ of the examined pellets contained one, two or four prey items respectively. For example, ten, nine and three pellets contained one rat, one bird or one hedgehog respectively. Pellets with two items included either two black rats $(\mathrm{n}=1)$, black rat and arthropod $(n=2)$, black rat and bird $(n=2)$, black rat and hedgehog $(\mathrm{n}=1)$, black rat and the starred agama lizard (Stellagama stellio) $(\mathrm{n}=1)$, bird and hedgehog $(n=1)$ and bird and arthropod $(n=2)$. Pellets with four prey items contained the remains of one bird, one hedgehog and two black rats; another with two hedgehogs, one black rat and one arthropod.
With 92 animal samples in total (33 in old samples, 59 in new samples) and 9 categories (Tab. 1; df $=8$ ) Pearson's test showed chi-square of 23.809 with $\mathrm{P}=$ 0.0025 (chi-square for the likelihood ratio was 26.791 with $\mathrm{P}=0.0008)$. The data thus show statistically significant difference between old and new samples.

\section{Pre y c h a r a c t e ris t i c s}

The average length of 45 intact $R$. rattus mandibles measured $24.31 \mathrm{~mm}$ (range 17.7-30.2 $\mathrm{mm}, \mathrm{SD} \pm 3.3$ ), with an average mandibular tooth row length of 6.55 $\mathrm{mm}$ (range 5.8-7 mm, SD \pm 0.33 ). Average skull length and width for five intact $R$. rattus skulls measured 47.26 $\mathrm{mm}$ range (44-48.9 $\mathrm{mm}, \mathrm{SD} \pm 1.98)$ and $22.36 \mathrm{~mm}$ (21.2-23.5 $\mathrm{mm}, \mathrm{SD} \pm 0.86)$ respectively. The average length of 34 intact $E$. concolor mandibles measured $32.14 \mathrm{~mm}$ (range $24.8-38.8 \mathrm{~mm}, \mathrm{SD} \pm 3.9$ ).

Most consumed black rats were of intermediate size (60.8\%, 21-27 mm lower jaw length), while smaller (17-20 $\mathrm{mm})$ and larger $(27.1-30.0 \mathrm{~mm})$ individuals accounted for a smaller proportion $(13.7 \%$ and $25.5 \%$ respectively). Among hedgehogs, larger individuals seemed to be favored $(61.8 \%, 30-38 \mathrm{~mm}$ lower jaw length) over smaller individuals $(32.4 \%, 24-29 \mathrm{~mm})$.

Tab. 1. Abundance of prey items found in pellets and prey remains of the Eurasian eagle owl (Bubo bubo) in Wadi Al Makhrour , Bethlehem, Palestinian Territories.

Tab. 1. Početnost' koristi nájdenej vo vývržkoch a zvyškoch koristi výra skalného (Bubo bubo) vo Wadi Al Makhrour, Betlehem, Palestínske územia.

\begin{tabular}{|c|c|c|c|c|c|c|}
\hline $\begin{array}{l}\text { taxon / } \\
\text { taxón }\end{array}$ & $\begin{array}{l}\text { recent pellets / } \\
\text { súčasné vývržky } \\
\text { No. of individuals / } \\
\text { počet jedincov }\end{array}$ & $\%$ & $\begin{array}{l}\text { older fragmented pe } \\
\text { staršie vývržky } \\
\text { No. of individuals / } \\
\text { počet jedincov }\end{array}$ & $\%$ & $\begin{array}{l}\text { total }(\%) / \\
\text { spolu }\end{array}$ & $\begin{array}{l}\text { No. in each pellet / } \\
\text { počet v každom vývžku }\end{array}$ \\
\hline Reptiles & 1 & 1.70 & 3 & 9.09 & 4.36 & \\
\hline Stellagama stellio & 1 & 18.61 & 3 & 9.09 & 4.36 & $0-2$ \\
\hline Mammals & 37 & 42.38 & 28 & 84.84 & 70.64 & \\
\hline Erinaceus concolor & 11 & 18.61 & 16 & 48.48 & 29.37 & $0-2$ \\
\hline Rattus rattus & 25 & 42.38 & 9 & 27.27 & 36.96 & $0-2$ \\
\hline Meriones tristrami & 0 & 0 & 1 & 3.03 & 1.08 & $0-1$ \\
\hline Microtus guentheri & 0 & 0 & 1 & 3.03 & 1.08 & $0-1$ \\
\hline Rousettus aegyptiacus & 0 & 0 & 1 & 3.03 & 1.08 & $0-1$ \\
\hline Domestic cat & 1 & 1.70 & 0 & 0 & 1.08 & $0-1$ \\
\hline Birds & 18 & 30.51 & 2 & 6.06 & 21.73 & \\
\hline Coloeus monedula & 4 & 6.78 & 1 & 3.03 & 5.44 & $0-1$ \\
\hline Alectoris chukar & 4 & 6.78 & 1 & 3.03 & 5.44 & $0-1$ \\
\hline Columba livia & 1 & 1.7 & 0 & 0 & 1.08 & $0-1$ \\
\hline Unidentfied birds & 9 & 15.25 & 0 & 0 & 9.79 & $0-1$ \\
\hline Arthropods & 3 & 5.10 & 0 & 0 & 3.24 & \\
\hline Scorpio maurus palmatus & 1 & 1.70 & 0 & 0 & 1.08 & $0-1$ \\
\hline Cerambycidae & 1 & 1.70 & 0 & 0 & 1.08 & $0-1$ \\
\hline Scarabaeidae & 1 & 1.70 & 0 & 0 & 1.08 & $0-1$ \\
\hline Total & 59 & 00.00 & 33 & 100.00 & 100.00 & \\
\hline
\end{tabular}




\section{Discussion}

The present work is the first report on the diet of eagle owls in Palestine. Samples from one reptilian species, the starred agama lizard, was found in the diet of the eagle owl. This is a common lizard in the rocky areas of Wadi Al Makhrour. Obuch (2014) reported multiple lizard species (Agamidae and Lacertidae) in eagle owl pellets from Iran. Our finding that hedgehogs constituted a significant part of the eagle owl diet is shared with most studies on this owl's diet, both within the Middle East (Shehab 2004) and elsewhere (Marchesi et al. 2002; De Cupere et al. 2009). Our data show increasing dependence on black rats in the diet. Previous studies showed black rats constituting $38 \%$ of the eagle owl diet in a forest on the outskirts of developed urban areas in Braşov, Romania (Sándor \& Ionescu 2009). In the central-eastern Italian Alps black rats constituted 28.5\% (Marchesi et al. 2002), and in Amvrakikos, Greece, up to $40 \%$ of the diet (Alivizatos et al. 2005). By contrast, in diets of owls far from developed areas commensal rats were rare: $3.9 \%$ in southern Portugal (Lourenço 2006), very few in Sagalassos, SW Turkey (De Cupere et al. 2009), $0.24 \%$ and $3.27 \%$ in the central and southern Zagros Mountains respectively (Obuch 2014), and 2.3\% from the Orava region, N Slovakia, for Rattus norvegicus (Obuch \& Karaska 2010).

There was a statistically significant difference in prey composition between old and new pellets. Prey items from old decomposed pellets contained more naturally-occurring species (i.e. Erinaceus concolor, $\mathrm{Me}$ riones tristrami, Microtus guentheri and Rousettus aegyptiacus). The latter three species were not recovered in the recently-regurgitated pellets, nor found in a recent survey of the Wadi Al Makhrour area (Qumsiyeh et al. 2014). In this respect this is similar to the diet of eagle owls in other places, especially where hedgehog is very abundant (e.g. Papageorgiou et al. 1993). Our results suggest that the invasive black rat is probably becoming increasingly common in the area at the expense of endemic species. This is probably due to anthropogenic alteration of the environment. As an opportunistic species, the eagle owl has adapted to this change in faunal composition over the past few decades. Qumsiyeh et al. (2014) gave independent evidence of this faunal change in this area as they documented a decline in vertebrate diversity in the Bethlehem area from the 1960 s/1970s to $2008-2013$ as a result of urbanization and other factors (Bethlehem has seen its district population increase over twelve-fold in the past seven decades and its built-up areas tripled). Our data on this owl's change in diet in time include additional worrisome items. While they indicate this particular owl's adaptability to changing circumstances, the additional evidence of deteriorating biodiversity in the area is troublesome. This is because an ecosystem dominated by one or a few species such as rats cannot be sustainable in the long term, and there is a need for intervention to halt catastrophic consequences (Hooper et al. 2005; Scheffer et al. 2001).

\section{References}

Alivizatos H, Goutner V \& Zogaris S 2005: Contribution to the study of the diet of four owl species (Aves, Strigiformes) from mainland and island areas of Greece. Belgian Journal of Zoology 135: $109-118$.

Amr ZS, Al-Melhim WN \& Yousef MA 1997: Mammal remains from pellets of the eagle owl, Bubo bubo, from Azraq Nature Reserve, Jordan. Zoology in the Middle East 14: 5-10. DOI: 10.1080/ 09397140.1997 .10637698

Charter M, Izhaki I, Shapira L \& Leshem Y 2007: Diets of urban breeding barn owls (Tyto alba) in Tel Aviv, Israel. The Wilson Journal of Ornithology 119:484-485. DOI: dx.doi.org/10.1676/06-109.1

Charter M, Izhaki I, Meyrom K, Motro Y \&Leshem Y 2009: Diets of barn owls differ in the same agricultural region. The Wilson Journal of Ornithology 121: 378-383. DOI: dx.doi.org/10.1676/08-083.1.

De Cupere B, Thys S, Van Neer W, Ervynck A, Corremans M \& Waelkens M 2009: Eagle owl (Bubo bubo) pellets from Roman Sagalassos (SW Turkey): Distinguishing the prey remains from nest and roost sites. International Journal of Osteoarchaeology 19: 1-22. DOI: 10.1002/oa.965.

Donázar JA 1987: Geographic variations in the diet of eagle owls in Western Mediterranean Europe, 220-224. In: Nero RW, Clark RJ, Knapton RJ \& Hamre R H (eds), Biology and Conservation of Northern Forest Owls. USDA Forest Service General Technical Report RM-142, Fort Collins, Colorado, 324.

Dor M 1947: Observations sur les micromammifères trouvés dans les pelotes de la chouette effraye (Tyto $a l b a$ ), en Palestine. Mammalia 11: 49-54. DOI: 10.1515/mamm.1947.11.1.50.

Evans MI \& Bates P 1993: Diet of the desert eagle owl in Harrat al Harrah reserve, northern Saudi Arabia. Ornithological Society of the Middle East Bulletin 30: 26. 
Goodman SM 1990: The food habits of the eagle owl (Bubo bubo ascalaphus) in Kharga Oasis, Egyptian Western Desert. Journal of Arid Environments 18: 217-220. DOI: 10.1006/jare.1999.0601.

Heth G 1991: Evidence of aboveground predation and age determination of the preyed, in subterranean mole rats (Spalax ehrenbergi) in Israel. Mammalia 55: 529-542. DOI: 10.1515/mamm.1991.55.4.529.

Hooper DU, Chapin III FS, Ewel JJ, Hector A, Inchausti P, Lavorel S, Lawton JH, Lodge D M, Loreau M, Naeem S, Schmid B, Setälä H, Symstad AJ, Vandermeer J \& Wardle DA 2005: Effects of biodiversity on ecosystem functioning: a consensus of current knowledge. Ecological Monographs 75: 3-35. DOI: 10.1890/04-0922.

Lourenço R 2006: The food habits of Eurasian eagleowls in southern Portugal. Journal of Raptor Research 40: 297-300. DOI: dx.doi.org/10.3356/08921016(2006)40[297:TFHOEE]2.0.CO;2.

Marchesi L, Sergio, F \& Pedrini P 2002: Costs and benefits of breeding in human-altered landscapes for the eagle owl, Bubo bubo. Ibis 144 (on line): E164-E177. DOI: 10.1046/j.1474-919X.2002.t01-200094 2.x

Obuch J 1994: On the food of the eagle owl (Bubo bubo) and tawny owl (Strix aluco) in the eastern part of Turkey. Tichodroma 7: 7-16.

Obuch J 2011: Spatial and temporal diversity of the diet of the tawny owl (Strix aluco). Slovak Raptor Journal 4: 1-120. DOI: 10.2478/v10262-012-0057-8.

Obuch J 2014: Spatial diversity in the diet of the Eurasian eagle owl Bubo bubo in Iran. Podoces 9: $7-21$.

Obuch J \& Benda P 2009: Food of the barn owl (Tyto $a l b a)$ in the Eastern Mediterranean. Slovak Raptor Journal 3: 41-50. DOI: 10.2478/v10262-012-0032-4.

Obuch J \& Karaska D 2010: The Eurasian eagle-owl (Bubo bubo) diet in the Orava Region (N Slovakia). Slovak Raptor Journal 4: 83-98. DOI: 10.2478/v10262-012-0048-9.
Papageorgiou NK, Vlachos CG \& Balkaloudis DE 1993: Diet and nest site characteristics of Eagle Owl (Bubo bubo) breeding in two different habitats in north-eastern Greece. Avocetta 17: 49-54.

Pokines JT \& Peterhans JCK 1998: Barn owl (Tyto alba) taphonomy in the Negev Desert, Israel. Israel Journal of Zoology 44: 19-27. DOI: 10.1080/00212210.1998.10688930.

Qumsiyeh M, Zavala S \& Amr Z 2014: Decline in vertebrate biodiversity in Bethlehem, Palestine. Jordan Journal of Biological Sciences 7: 101-107.

Rifai LB, Al-Melhim WN, Gharaibeh BM \& Amr Z 2000: The diet of the desert eagle owl, Bubo bubo ascalaphus, in the Eastern Desert of Jordan. Journal of Arid Environments 44: 369-372. DOI: 10.1006/jare.1999.0601.

Sándor AD \& Ionescu DT 2009: Diet of the eagle owl (Bubo bubo) in Braşov, Romania. North-Western Journal of Zoology 5: 170-178.

Scheffer M, Carpenter S, Foley JA, Folke C \& Walker B 2001: Catastrophic shifts in ecosystems. Nature 413: 591-596. DOI: $10.1038 / 35098000$.

Shehab AH 2004: Diet of the eagle owl, Bubo bubo, in Syria. Zoology in the Middle East 33: 21-26. DOI: 10.1080/09397140.2004.10638060.

Shehab AH \& Ciach M 2008: Diet composition of the pharaoh eagle owl, Bubo ascalaphus, in Azraq Nature Reserve, Jordan. Turkish Journal of Zoology 32: 65-69.

Shirihai H 1996: The Birds of Israel. Academic Press, London.

Tores M \& Yom-Tov Y 2003: The diet of the barn owl Tyto alba in the Negev Desert. Israel Journal of Zoology 49: 233-236. DOI: 10.1560/JU3E-EWK413QY-CGRF.

Yom-Tov Y \& Wool D 1997: Does the contents of barn owl pellets accurately represent the proportion of prey species in the field? Condor 99: 972-976. 